\title{
DYNAMICS OF MINERAL NITROGEN COMPOUNDS IN THE WATERS OF THE DNIESTER RIVER
}

\author{
Petru Ciorba ${ }^{1}$, Elena Zubcov ${ }^{1}$, Nina Bagrin ${ }^{1}$, Liliana Teodorof ${ }^{2}$
}

${ }^{1}$ Institute of Zoology, Chisinau, Republic of Moldova, e-mail: petru.ciorba@zoology.md,

${ }^{2}$ Danube Delta National Institute, Tulcea, Romania

\begin{abstract}
This article presents the results of studying the content of mineral (ammonium ions, nitrites and nitrates) and organic nitrogen compounds in water samples collected from the Dniester river in 2020. In the study are examines the seasonal dynamics of the forms of mineral nitrogen, total nitrogen and the correlation between organic and mineral nitrogen. Limits of ammonium ion concentration in the Dniester river varied between $0.002 \mathrm{mg} \mathrm{N} / 1$ and $0.93 \mathrm{mg} \mathrm{N} / 1$, nitrite ions $0.002 \mathrm{mg} \mathrm{N} / 1$ and $0.05 \mathrm{mg} \mathrm{N} / 1$, nitrate ions $0.002 \mathrm{mg} \mathrm{N} / 1-1.36 \mathrm{mg} \mathrm{N} / 1$.
\end{abstract}

\section{Introduction}

Dniester is one of the largest rivers of Europe. It flows from the north-western part of the Eastern Carpathians, the mountain slope Rozlici, its length being equal to $1352 \mathrm{~km}$, the basin area $-72,100 \mathrm{~km}$, including the Moldovan territory of $657 \mathrm{~km}$ and 19,000 km, respectively. The average annual flow reaches up to $10 \mathrm{~km}$ [5].

For the Dniester River, as well as for all surface waters, the content of nitrates, nitrites and ammonium nitrogen are important indicators of the chemical composition of water, which are taken into account when assessing the ecological impact and regulating water quality. Knowing the concentrations of mineral nitrogen compounds and the ratio between organic and mineral nitrogen, helps to identify in time the existence of conditions for the development of anthropogenic eutrophication [2]. In aquatic ecosystems, mineral nitrogen compounds (ammonium ions, nitrites and nitrates) are mutually dependent and can change from one form to another, so it is important to monitor them as a whole.

Mineral nitrogen compounds are often determinants in the development of aquatic organisms, in the intensity of the production-destructive processes of primary producers of hydrobionts and different groups of aquatic microorganisms and the level of trophicity of ecosystems.

Mineral nitrogen compounds are biogenic substances, but under certain conditions generated by anthropogenic activity (use of fertilizers, discharge of wastewater) can become toxic substances. [4]

Monitoring these compounds and other biogenic substances allows estimating changes in the aquatic environment, assessing the intensity of migration and the chemical circuit, assessing their impact on hydrobionts, as well as establishing the legitimacy of hydrobiocenosis and preventing adverse consequences on ecosystems.

\section{Materials and methods}

Water samples were collected from the Dniester river in the collection points Naslavcea, Valcinet, Soroca, Camenca, Erjova, Goieni, Cocieri, Vadul lui Voda, Varnița, Sucleia, Palanca, 
during 2020 in February, May, June (flood period), July, October (fig. 1).

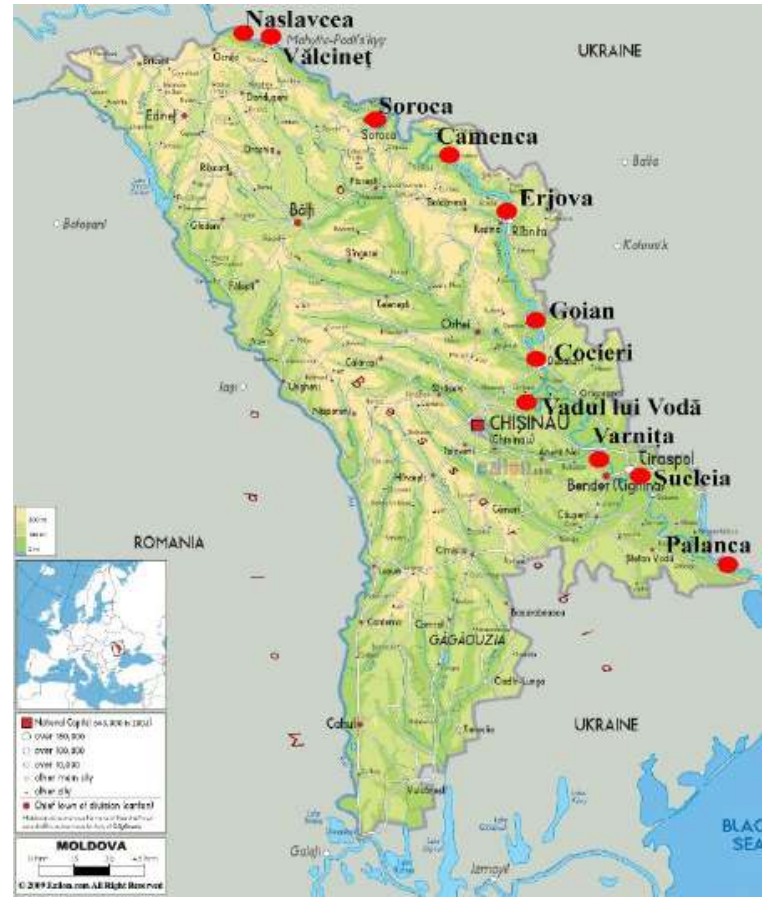

Figure 1. Sample collection points from the Dniester river: Naslavcea, Valcinet, Soroca, Camenca, Erjova, Goian, Cocieri, Vadul lui Voda, Varnita, Sucleia, Palanca

The content of nitrates, nitrites and ammonium ions was determined by the spectrophotometric method [1].

The principle of the method for determining nitrites consists in the formation of a diazonic compound of color from pink to red, the intensity increasing with increasing concentration.50 $\mathrm{ml}$ of analyte water are taken into the flask $(50 \mathrm{ml}), 0.1 \mathrm{~g}$ of Griess reagent is added. Mix well and leave for $40 \mathrm{~min}$. for color development. After $40 \mathrm{~min}$. the optical density is measured at the spectrophotometer $(\lambda=540 \mathrm{~nm})$ in $10 \mathrm{~mm}$ cuvettes in relation to the water to be analyzed.

The method of determining nitrates consists in determining the color intensity of the nitro derivatives formed by the chemical reaction between salicylic acid and nitrates in water in an acidic medium. Take $10 \mathrm{ml}$ of the test sample in the beaker $(50 \mathrm{ml})$. Add $1 \mathrm{ml}$ of sodium salicylate (freshly prepared). Place the sample beaker in the oven (or water bath) on evaporation and keep to dry. After beaker cooling to room temperature, add $1 \mathrm{ml}$ of concentrated sulfuric acid ( $\rho=1.84 \mathrm{~g} / \mathrm{l}$ ), moisten the walls of the beaker well and leave for 10-15 minutes. Meanwhile, by slow rotating movements of the beaker, the acid "drips" well on the walls of the beaker for a total dissolution. After 15 minutes, wash the walls of the beaker well with distilled water and transfer to a $50 \mathrm{ml}$ volumetric flask. Add $7 \mathrm{ml}$ of $\mathrm{NaOH}(10 \mathrm{~N})$ to the beaker and make up to volume with distilled water. Put the lid on and mix well. After $10 \mathrm{~min}$. measure the optical density of the solution in cuvettes of $10 \mathrm{~mm}$ at $\lambda=400 \mathrm{~nm}$ in relation to the analyzed water. In the case of water with a high nitrate content, $1 \mathrm{ml}$ of test sample will initially be taken. 
The principle of determination of ammonium ions consists in the reaction of ammonium ions, in basic medium, with potassium tetraiodomercurate ( $\mathrm{K} 2$ [HgI4]) which forms a yellow-brown complex (oxymercur ammonium iodide). The color intensity is proportional to the ammonium ion content of the sample to be analyzed. Take $50 \mathrm{ml}$ of the test sample into the volumetric flask $(50 \mathrm{ml})$, add $1 \mathrm{ml}$ of Seignette salt and mix well. Then add $1 \mathrm{ml}$ of Nessler reagent. The obtained solution is mixed well and left for 7-10 minutes to develop the color. After $10 \mathrm{~min}$ the optical density of the solution is measured in cuvettes of $10 \mathrm{~mm}$ at at $\lambda=400 \mathrm{~nm}$ in relation to the analyzed water.

The UV-VIS Specord 210 Plus spectrophotometer (Analytik Jena, Germany) was used to measure the optical densities.

\section{Results and discussions}

Maximum concentrations of ammonium ions were obtained in February in Varnita. In most of the samples from Naslavcea to Vadul lui Voda in February and October, non-essential changes of ammonium ion concentrations are observed. In Varnita throughout the year there is a high level of ammonium ions, in February about 6 times more than upstream, in May dozens of times, October 3 times, a fact observed downstream in Sucleia in February and Palanca in May. This can be argued as a result of diversions from the Bic river, a tributary of the Dniester river, whose mouth is located upstream of Varnita and the concentrations of ammonium ions being 10 times higher than in Varnita in May. In June (flood period) there is no major difference between concentrations (fig. 2).

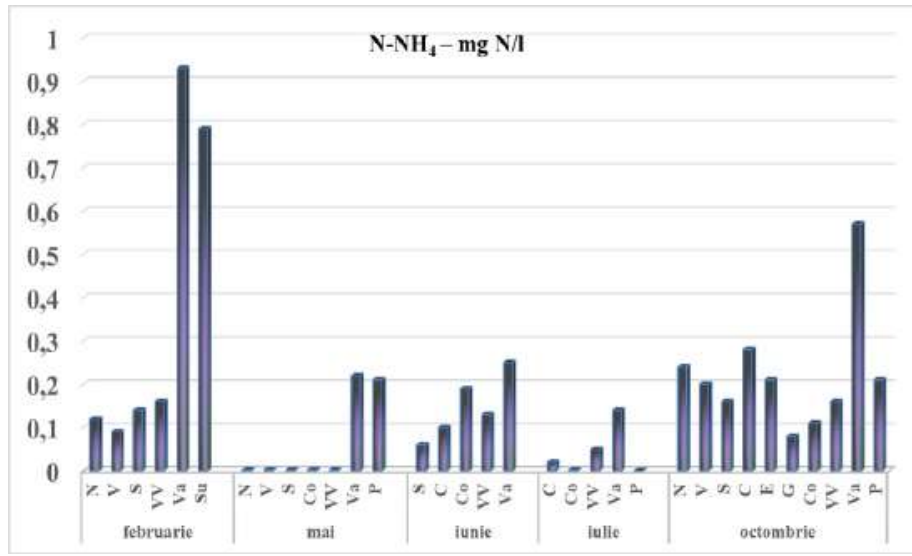

Figure 2. Dynamics of ammonium cation concentration $(\mathrm{N}-\mathrm{NH} 4+)$ in the Dniester waters in $\mathrm{mg}$ N/l (N-Naslavcea, V-Valcinet, S-Soroca, C-Camenca, E-Erjova, G- Goian, Co-Cocieri, VV-Vadul lui Voda, Va-Varnita, Su-Sucleia, P-Palanca)

According to the Regulation on environmental quality requirements for surface waters [3], according to the content of ammonium ions, Dniester river refers to quality classes I and II, very good and good water respectively, only in February in Sucleia and in October in Varnita - it referred to quality class III (moderately polluted), reaching in February in Varnita even the class IV - polluted. 


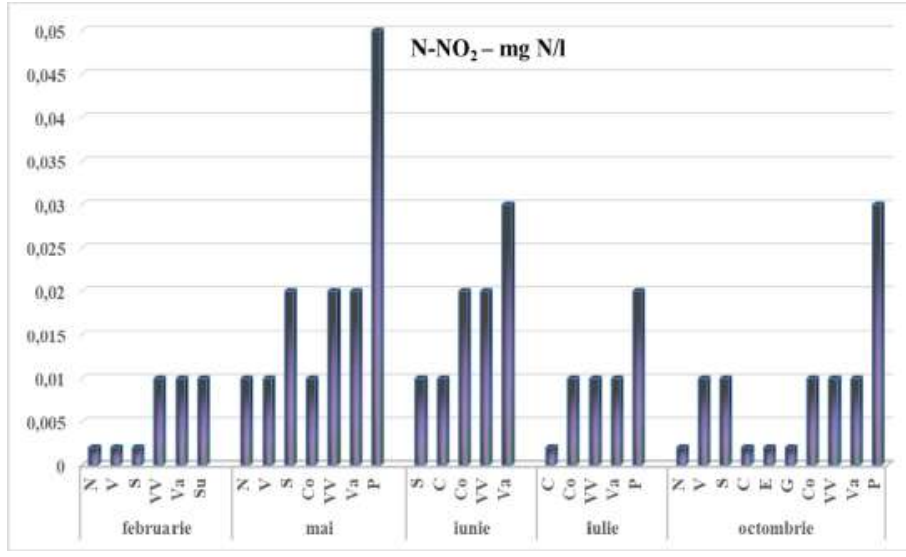

Figure 3. Dynamics of nitrite anion concentration (N-NO2-) in the Dniester waters in $\mathrm{mg}$ N/l (N-Naslavcea, V-Valcinet, S-Soroca, C-Camenca, E-Erjova, G-Goian, Co-Cocieri, VV-Vadul lui Voda, Va-Varnita, Su-Sucleia, P-Palanca)

Nitrites are the intermediate step between ammonium ions and nitrates. In the waters of the Dniester river in 2020 the nitrite concentrations were low, the vast majority being up to 0.02 $\mathrm{mg}$ N/1. The maximum values were determined in Palanca in May and October and in Varnita in June (fig. 3).

According to the quality requirements for surface waters, the waters of the Dniester River referred to classes I (very good water) and II (good water) of quality [3].

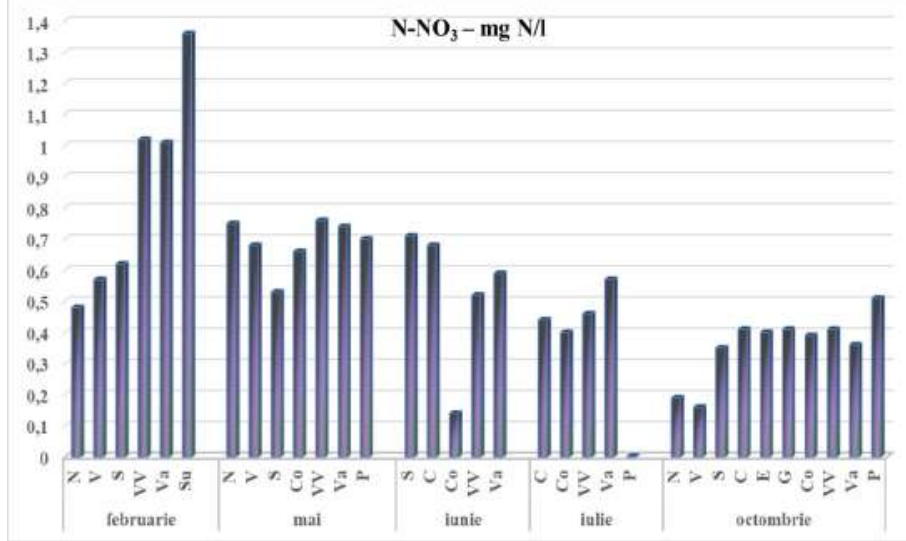

Figure 4. Dynamics of nitrate anion concentration (N-NO3-) in the Dniester waters in mg N/l (N-Naslavcea, V-Valcinet, S-Soroca, C-Camenca, E-Erjova, G-Goian, Co-Cocieri, VV-Vadul lui Voda, Va-Varnita, Su-Sucleia, P-Palanca)

According to the Regulation on environmental quality requirements for surface waters [3], according to the content of ammonium ions, Dniester river refers to quality classes I and II, very good and good water respectively, only in February in Sucleia and in October in Varnita - it referred to quality class III (moderately polluted), reaching in February in Varnita even the class IV - polluted. 


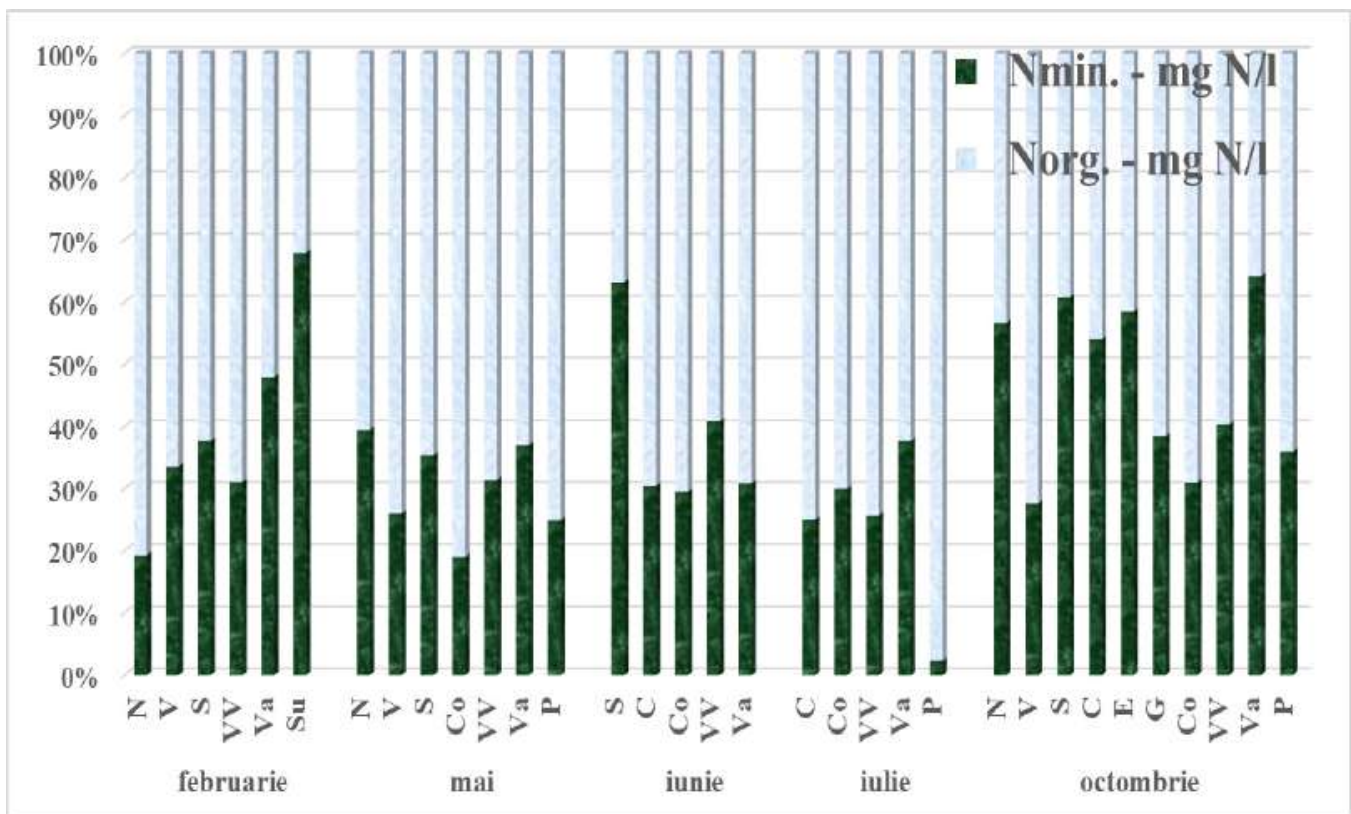

Figure 5. Dynamics of the ratio between Nmin. with Norg. (N-Naslavcea, V-Valcinet, S-Soroca, C-Camenca, E-Erjova, G-Goian, Co-Cocieri, VV-Vadul lui Voda, Va-Varnita, Su-Sucleia, P-Palanca)

Practically along all the Dniester river and throughout the year there is a dominance of organic nitrogen. In February, May, June and July we notice that the organic nitrogen content represents from 53\% to 82\%, and in Palanca in July 99\% and only in the points Sucleia in February and Soroca in June (flood period) predominate the mineral forms of azote. In October, there is an increase in the share of mineral nitrogen from $29 \%$ to $63 \%$ of the total nitrogen content, the majority being in half of the sample collection points (fig. 5).

Total nitrogen concentrations during the year were in the range of $0.86-4.07 \mathrm{mg} \mathrm{N} / 1$. According to the quality requirements for surface waters, the concentrations of total nitrogen the Dniester river correspond to class I (very good water) and class II (good water) of quality and only in Varnita in February the waters refer to class III of quality - moderately polluted [3].

\section{Conclusions}

1. The concentrations of mineral nitrogen forms in the Dniester waters largely correspond to quality classes I and II, very good and good waters.

2. Nitrate concentrations largely prevailed throughout the year over ammonium ions and nitrites.

3. The Dniester river in 2020 in most cases was, largely favorable for the development of aquatic organisms.

4. Organic nitrogen predominates in most cases throughout the year over mineral forms of nitrogen. 
Acknowledgements. The authors are thankful to the national project 20.80009.7007.06 "Determining changes in the aquatic environment, assessing migration and impact of polluants, establishing the legitimacy of hydrobiocenosis and preventing adverse consequences on ecosystems" - AQUABIO (State Program 2020-2023) and to the EU Black Sea Joint Operational Programme 2014-2020 for the funding of the project with eMS code eMS BSB 27" Black Sea Basin interdisciplinary cooperation network for sustainable joint monitoring of environmental toxicants migration, improved evaluation of ecological state and human health impact of harmful substances, and public exposure prevention - MONITOX". The content of this publication is sole responsiblity of the authors and does not reflect the views of the European Union.

\section{Bibliography}

1. Monitoringul calității apei și evaluarea stării ecologice a ecosistemelor acvatice: Îndrumar Metodic/ Acad. de Științe a Moldovei, Inst. de Zoologie, Univ. Acad. de Științe a Moldovei:. Chişinău, 2015, Tipogr. "Elan Poligraf", 84 p.

2. Novic Anastasia A, Shannin Alexei A. The determination of the nitrogen-containing ions concentrations dynamics in the oxbow of Ishimchik to assess the impact of 2016-2017 floods. In: Samara Journal of Science Bd. 9, ECO-Vector LLC (2020), Nr. 2, S. 98-101

3. Regulamentul cu privire la cerințele de calitate a mediului pentru apele de suprafață. Hotărârea Guvernului nr. 890 din 22.11.2013 în Monitorul Oficial Nr. 262-267 art. Nr. : 1006.

4. Rozhdestvenskaya T.A., Puzanov A.V., Gorbachev I.V. Nitrates and nitrites in the surface and ground water of Altai, Мир Науки, Культуры, Образования, o2(9), 2008

5. Zubcov E., Ungureanu L., Ene A., Zubcov N., Bagrin N., Borodin N., Lebedenco L., Biletchi L. Assessment of chemical compositions of water and ecological situation in Dniester River. Journal of Science and Arts Year 10, No.1 (12), p. 47-52, 2010, Chemistry Section, http://www.josa.ro/ro/index.html?http\%3A//www.josa. ro/ro/josa.html 